\title{
Pollution Prevention Assessment for a Manufacturer of
}

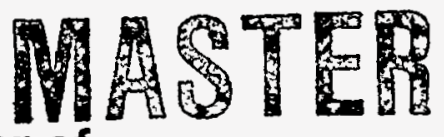

\section{Outboard Motors}

\author{
Richard J. Jendrucko", Thomas N. Coleman;, and \\ Gwen P. Looby"*
}

\author{
AECEIVED
}

\begin{abstract}
The U.S. Environmental Protection Agency (EPA) has funded a pilot project to assist small and medium-size manufacturers who want to minimize their generation of waste but who lack the expertise to do so. In an effort to assist these manufacturers Waste Minimization Assessment Centers (WMACs) were established at selected universities and procedures were adapted from the EPA Waste Minimization Opportunity Assessment Manual (EPA/625/7-88/003, July 1988). That document has been superseded by the Facility Pollution Prevention Guide (EPA/600/R-92/088, May 1992). The WMAC team at the University of Tennessee performed an assessment at a plant that manufactures outboard motors for water craft. Three basic subunits received from other manufacturing plants undergo primarily painting and assembly operations in order to produce the final product. The team's report, detailing findings and recommendations, indicated that paint overspray waste and spent clean-up solvent are generated in large quantities and that significant cost savings could be achieved by installing robotic paint application equipment.
\end{abstract}

This Research Brief was developed by the principal investigators and EPA's National Risk Management Research Laboratory, Cincinnati, $\mathrm{OH}$, to announce key findings of an ongoing research project that is fully documented in a separate report of the same title available from University City Science Center.

\section{Introduction}

The amount of waste generated by industrial plants has become an increasingly costly problem for manufacturers and an additional stress on the environment. One solution to the

\footnotetext{
- University of Tennessee, Department of Engineering Science and Mechanics

- University City Science Center, Philadelphia, PA
}

problem of waste generation is to reduce or eliminate the waste at its source.

University City Science Center (Philadelphia, PA) has begun a pilot project to assist small and medium-size manufacturers who want to minimize their generation of waste but who lack the in-house expertise to do so. Under agreement with EPA's National Risk Management Research Laboratory, the Science Center has established three WMACs. This assessment was done by engineering faculty and students at the University of Tennessee WMAC. The assessment teams have considerable direct experience with process operations in manufacturing plants and also have the knowledge and skills needed to minimize waste generation.

The pollution prevention opportunity assessments are done for small and medium-size manufacturers at no out-of-pocket cost to the client. To qualify for the assessment, each client must fall within Standard Industrial Classification Code 20-39, have gross annual sales not exceeding $\$ 75$ million, employ no more than 500 persons, and lack in-house expertise in pollution prevention.

The potential benefits of the pilot project include minimization of the amount of waste generated by manufacturers, and reduction of waste treatment and disposal costs for participating plants. In addition, the project provides valuable experience for graduate and undergraduate students who participate in the program, and a cleaner environment without more regulations and higher costs for manufacturers.

\section{Methodology of Assessments}

The pollution prevention opportunity assessments require several site visits to each client served. In general, the WMACs follow the procedures outlined in the EPA Waste Minimization Exy Printed on Recycled Paper

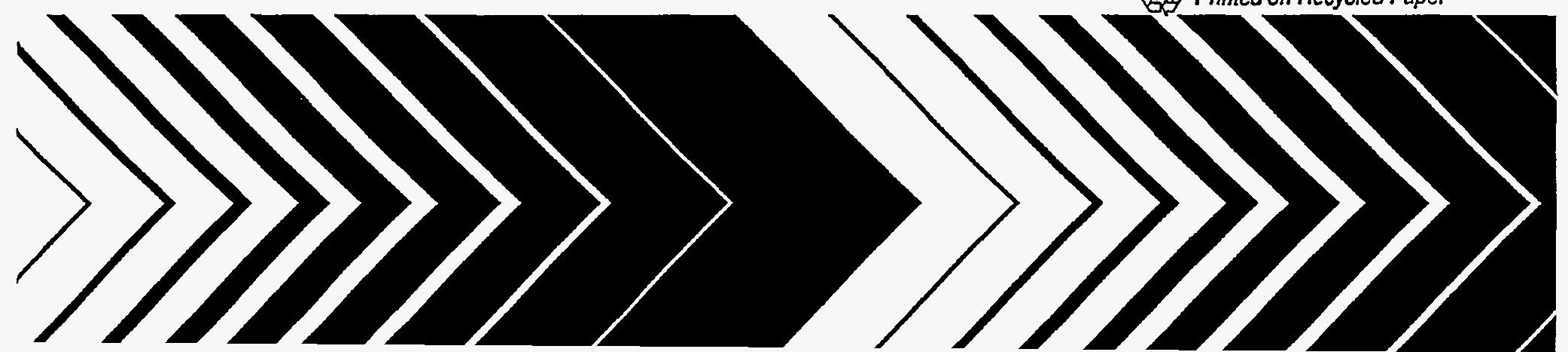


Opportunity Assessment Manual (EPA/625/7-88/003, July 1988). The WMAC staff locate the sources of waste in the plant and identify the current disposal or treatment methods and their associated costs. They then identify and analyze a variety of ways to reduce or eliminate the waste. Specific measures to achieve that goal are recommended and the essential supporting technological and economic information is developed. Finally, a confidential report that details the WMAC's findings and recommendations (including cost savings, implementation costs, and payback times) is prepared for each client.

\section{Plant Background}

Approximately 140,000 finished water craft outboard motors are manufactured by this plant, which is a final assembly facility. It operates 2,000 hr/yr.

\section{Manufacturing Process}

Three basic subunits received from other manufacturing plants, component parts, hardware, paint and primer, and decals are used to produce the outboard motors. The production operations required can be classified as lower-unit subassembly, power-head subassembly, motor cover subassembly, and final assembly. Each of the production operations will be described here.

\section{Lower-unit Subassembly}

The lower units, which are received in two parts, are bolted together in this plant. First, the connection surface on each part is polished and then a primer coating is applied. After coating, the part surfaces are cleaned manually.

Lower-unit subassemblies are then sent through a five-stage washer in preparation for painting. Following the final rinse of the five-stage washer, water is removed from internal surfaces and cavities with pressurized air. Masking is applied to protect areas of the lower units that do not require painting and then the subassemblies are conveyed through a dry-off oven for further water removal.

Primer is applied in one of two primer spray booths where the required coating is manually applied with electrostatic spray guns. The subassemblies are then conveyed through a curing oven. Next, the units are cleaned and conveyed through one of the topcoat spray booths where the final cosmetic coating is manually applied. The subassemblies are then conveyed through a final curing oven.

The finished lower units are inspected for defects and any rejected units are rewashed and repainted. Masking is manually removed from accepted parts, which are transferred to final assembly.

\section{Power-head Subassembly}

Various types and sizes of power heads (internal combustion engines) are received in almost ready-to-use condition. Various parts including carburetors, solenoids, and starters are bolted onto the power head subassemblies using metal fasteners that have been dipped in a lubricant. The power-head subassemblies are then transferred to the final assembly area.

\section{Motor Cover Subassembly}

Motor covers are received as unpainted fiberglass shells. The shells are processed through a three-stage washer for grease and dirt removal. Next, the clean motor covers are conveyed through a spray paint booth where primer is manually applied with high-volume low-pressure spray guns. The primer is then cured in an oven.

Following primer curing, the covers are conveyed through one of two spray booths where either a basecoat or a topcoat is applied. The motor covers that receive basecoat paint are conveyed through a flash-off tunnel, where some drying occurs, to one of two clearcoat paint booths where a clear finish is applied over the basecoat.

Motor covers from the clearcoat booths and covers from topcoating are conveyed through an oven for curing. The completed motors are inspected for coating imperfections and rejected covers are transferred to a sanding booth and then back to the 3-stage washer for reprocessing. Accepted covers are transferred to a motor cover detailing operation where decals and molding are attached manually. The finished covers are transferred to final assembly.

\section{Final Assembly}

In final assembly, power heads are bolted onto lower units which are then filled with gear-case oil. The assembled motors are tested in water tanks. Units that fail testing are repaired and retested. Accepted motors are degassed using compressed air.

Finally, the motor covers are placed over the power-heads and attached to the power units. The completed motors are then spot-cleaned as needed and any required touch-up painting is performed. Finished motors are packaged and shipped to customers.

An abbreviated process flow diagram for outboard motor manufacture is shown in Figure 1.

\section{Existing Waste Management Practices}

This plant already has implemented the following techniques to manage and minimize its wastes.

- Wet scrubber paint booths have been converted to a dry filter system in order to eliminate the generation of a wastewater stream containing hexavalent chromium.

- The cleaning process for small paint pots has been converted from a simple solvent rinse to an automatic solvent spray cleaning system in order to reduce the quantity of solvent used.

- A crank-case oil waste stream has been eliminated by collecting spills and drips and reusing them.

- Approximately $50 \%$ of raw material shipments are received in reusable packaging.

- Cardboard packaging and office paper are recycled.

- Clearcoat paint application has been converted to robotic paint application in order to achieve increased paint transfer efficiency and improved coating appearance.

\section{Pollution Prevention Opportunities}

The type of waste currently generated by the plant, the source of the waste, the waste management method, the quantity of the waste, and the annual treatment and disposal cost for each waste stream identified are given in Table 1. 


\section{DISCLAIMER}

This report was prepared as an account of work sponsored by an agency of the United States Government. Neither the United States Government nor any agency thereof, nor any of their employees, makes any warranty, express or implied, or assumes any legal liability or responsibility for the accuracy, completeness, or usefulness of any information, apparatus, product, or process disclosed, or represents that its use would not infringe privately owned rights. Reference herein to any specific commercial product, process, or service by trade name, trademark, manufacturer, or otherwise does not necessarily constitute or imply its endorsement, recommendation, or favoring by the United States Government or any agency thereof. The views and opinions of authors expressed herein do not necessarily state or reflect those of the United States Government or any agency thereof. 


\section{DISCLAIMER}

Portions of this document may be illegible in electronic image products. Images are produced from the best available original document. 
Table 2 shows the opportunities for pollution prevention that the WMAC team recommended for the plant. The opportunity, the type of waste, the possible waste reduction and associated savings, and the implementation cost along with the simple payback time are given in the table. The quantities of waste currently generated by the plant and possible waste reduction depend on the production level of the plant. All values should be considered in that context.

It should be noted that the economic savings of the opportunity, in most cases, results from the reduction in raw material and from reduced present and future costs associated with waste treatment and disposal. Other savings not quantifiable by this study include a wide variety of possible future costs related to changing emissions standards, liability, and employee health. It also should be noted that the savings given for each opportunity reflect that pollution prevention opportunity only and do not reflect duplication of savings that may result when the opportunities are implemented in a package.

This research brief summarizes a part of the work done under Cooperative Agreement No. CR-819557 by the University City Science Center under the sponsorship of the U.S. Environmental Protection Agency. The EPA Project Officer was Emma Lou George. 


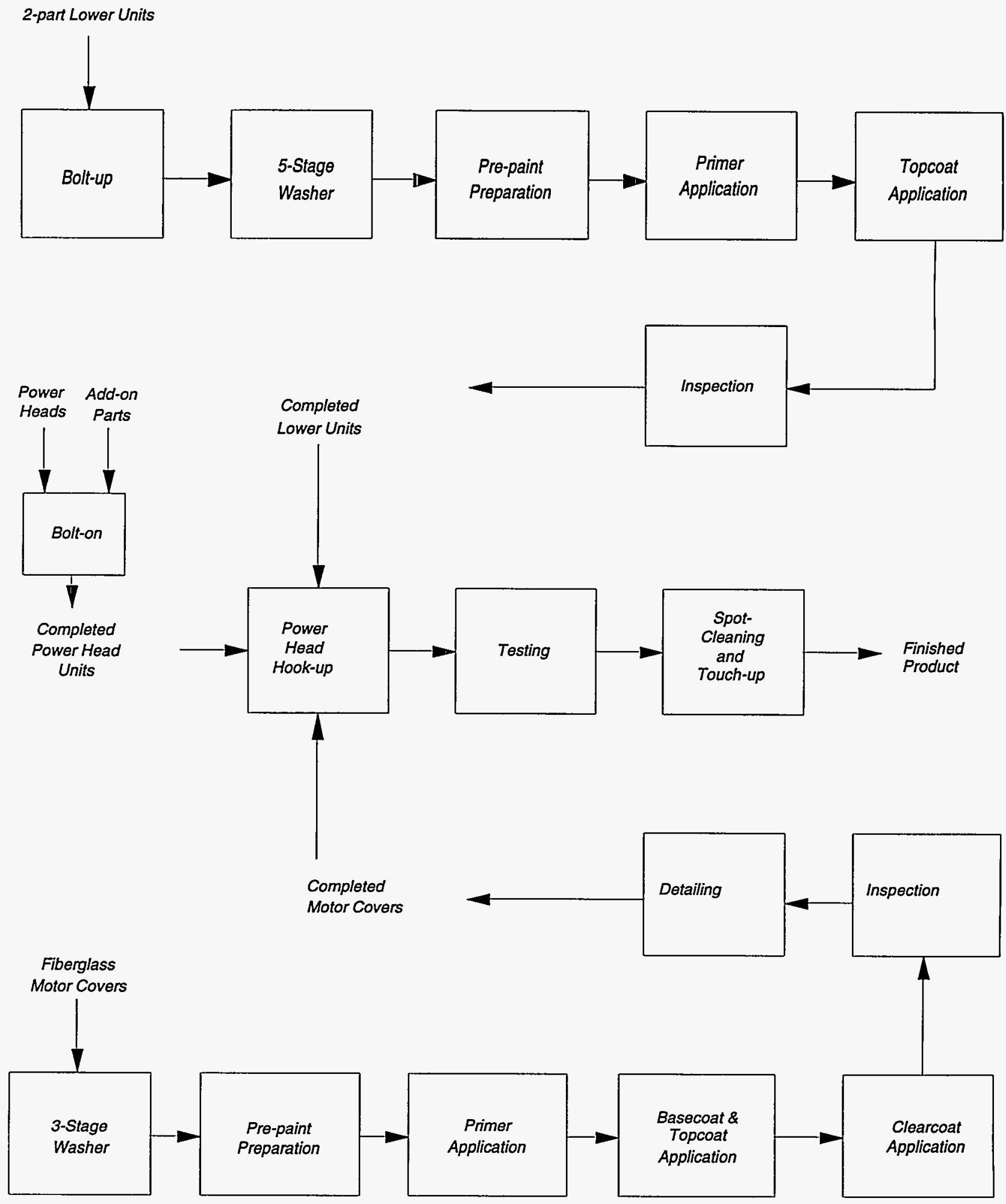

Figure 1. Abbreviated process flow diagram for outboard motor production. 
Table 1. Summary of Current Waste Generation

\begin{tabular}{|c|c|c|c|c|}
\hline Waste Stream Generated & Source of Waste & Waste Management Method & $\begin{array}{l}\text { Annual Quantity } \\
\text { Generated (lb/yr) }\end{array}$ & $\begin{array}{c}\text { Annual Waste } \\
\text { Management Cost }\end{array}$ \\
\hline Cardboard packaging material & Incoming materials & Baled; shipped offsite for recycle & 500,000 & $\begin{array}{c}\$-2,800 \\
\text { (net revenue received) }\end{array}$ \\
\hline Waste chromate material & Lower-unit bolt up, primer application & Shipped offsite for disposal & 67,530 & 115,530 \\
\hline Evaporated clean-up solvent & $\begin{array}{l}\text { Cleaning of subassemblies, paint and } \\
\text { primer lines, and finished units }\end{array}$ & Evaporates to plant air & 21,400 & 0 \\
\hline Rinse water & Five-stage washer & Sewered & $11,765,250$ & 2,100 \\
\hline Waste paint-related material & Painting of subassemblles & Shipped offsite for disposal & 4,200 & 13,215 \\
\hline Evaporated paint carrier solvent & Painting of subassemblies & Evaporates to plant air & 114,060 & 0 \\
\hline Spent clean-up solvent & Cleaning of paint lines and equipment & Shipped offsite for recycling & 122,310 & 61,160 \\
\hline Spent air filters and paint arrestors & Paint booths for subassemblles & Incinerated onsite & 117,630 & 19,740 \\
\hline Spent "wool grease" Iubricant & Lubrication of fasteners & Shipped offsite for disposal & 480 & 1,220 \\
\hline Evaporated water & Three-stage washer & Evaporates to plant air & $1,120,500$ & 0 \\
\hline Rinse water & Three-stage washer & Sewered & $3,921,750$ & 650 \\
\hline Gasoline/water & Motor degreasing following testing & Shipped offsite for use in fuels blending & 5,400 & 2,280 \\
\hline Unused paint & Painting of subassemblies & Shipped offsite for disposal & 2,860 & 3,270 \\
\hline Miscellaneous solid waste & Various plant operations & Shipped offsite to landfill & $4,860,000$ & 14,760 \\
\hline
\end{tabular}

1 includes waste treatment, dlsposal, and handling costs. 
Table 2. Summary of Recommended Pollution Prevention Opportunities

\begin{tabular}{|c|c|c|c|c|c|c|}
\hline \multirow[b]{2}{*}{ Pollution Prevention Opportunity } & \multirow[b]{2}{*}{ Waste Reduced } & \multicolumn{2}{|c|}{ Annual Waste Reduction } & \multirow{2}{*}{$\begin{array}{l}\text { Net Annual } \\
\text { Savings }\end{array}$} & \multirow{2}{*}{$\begin{array}{l}\text { Implementation } \\
\text { Cost }\end{array}$} & \multirow[b]{2}{*}{$\begin{array}{l}\text { Simple } \\
\text { Payback }(y r)\end{array}$} \\
\hline & & Quantity (lb/yr) & Por Cent & & & \\
\hline $\begin{array}{l}\text { Convert all manual spray painting operations to } \\
\text { robotic paint application. }\end{array}$ & $\begin{array}{l}\text { Waste chromate material } \\
\text { Spent alr filters and paint arrestors }\end{array}$ & $\begin{array}{l}16,640 \\
85,340\end{array}$ & $\begin{array}{l}25 \\
73\end{array}$ & $\$ 1,104,800^{1}$ & $\$ 2,139,100$ & 1.9 \\
\hline $\begin{array}{l}\text { Convert to electrostatic painting in topcoat spray } \\
\text { booths and improve electrostatic painting in } \\
\text { lower-unit primer booths. }\end{array}$ & $\begin{array}{l}\text { Waste chromate material } \\
\text { Spent air filters and paint arrestors }\end{array}$ & $\begin{array}{l}17,530 \\
34,320\end{array}$ & $\begin{array}{l}26 \\
29\end{array}$ & 290,018 & 34,840 & 0.1 \\
\hline $\begin{array}{l}\text { Determine an optimum painting schedule to } \\
\text { reduce the quantity of waste solvent generated } \\
\text { as a result of color changes. }\end{array}$ & Spent clean-up solvent & 48,500 & 40 & 34,580 & 15,000 & 0.4 \\
\hline $\begin{array}{l}\text { Use compressed air to blow topcoat and base- } \\
\text { coat paint remaining in individual paint gun } \\
\text { distributton lines back into recirculating } \\
\text { paint lines. }\end{array}$ & Spend clean-up solvent & 24,250 & 20 & 27,350 & 2,570 & 0.1 \\
\hline $\begin{array}{l}\text { Recover spent clean-up solvent onsite using a } \\
\text { distillatlon unit. A small quantity of still bottoms } \\
\text { will be generated and shipped offsite as hazard- } \\
\text { ous waste if this opportunity is implemented. }\end{array}$ & Spent clean-up solvent & 122,310 & 100 & 24,430 & 66,460 & 2.7 \\
\hline $\begin{array}{l}\text { Replace air fitters and paint arrestors on an } \\
\text { "as-needed" basis only. }\end{array}$ & $\begin{array}{l}\text { Waste chromate material } \\
\text { Spent air filters and paint arrestors }\end{array}$ & $\begin{array}{r}4,754 \\
23,526\end{array}$ & $\begin{array}{r}7 \\
20\end{array}$ & 21,164 & 0 & 0 \\
\hline $\begin{array}{l}\text { Purchase coatings in } 300 \text {-gal reusable totes } \\
\text { instead of } 5 . \text { gal containers that are currently } \\
\text { disposed of as hazardous waste. }\end{array}$ & Waste paint-related material & 2,100 & 50 & 6,420 & 0 & 0 \\
\hline $\begin{array}{l}\text { Reuse waste gasoline for subsequent } \\
\text { motor tests. }\end{array}$ & Gasoline/water & 5,400 & 100 & 1,220 & 0 & 0 \\
\hline
\end{tabular}

1 Includes labor cost savings. 